\title{
Entrepreneurial risk allocation in public-private infrastructure provision in South Africa
}

\author{
F. Ahwireng-Obeng* and J.P. Mokgohlwa \\ The Graduate School of Business Administration, University of the Witwatersrand, \\ PO Box 98, Wits 2050, Republic of South Africa \\ Ahwireng-Obeng.F@wbs.wits.ac.za \\ Received October 2002
}

\begin{abstract}
A primary concern in the development of entrepreneurship through private-public partnerships (PPP) in infrastructure projects is the adversarial, complex and unequal power relations characterising the negotiation of project risk allocation (RA) among the multiple participants. The inertia of the RA process has led to delayed and costly financial closure and sub-economic costs. Transactions costs of up to ten percent have been incurred in documented cases, and the situation is exacerbated in emerging economies, like South Africa, by political and economic instability and unproven track record of
\end{abstract} PPP.

These developments have led to frustration among private sector participants in PPPs and diminished incentives for their continued participation. Therefore, delivering "satisfactory" RA processes is critical for attracting both domestic and foreign private entrepreneurial resources.

The aim of this paper was to ascertain 'critical factors' influencing RA processes; determine the extent to which PPP practices in South Africa have led to equitable entrepreneurial risk allocation; and assess the choice of contract for implementing the outcomes of PPP negotiations.

Critical success factors included: limiting apprehensions about market, socio-political, regulatory and legal risks as well as risk of lenders; improving common understanding among PPP participants; enhancing the quality of RFP (request for proposal) processes; and strengthening the commitment of participants. RA practices regarding socio-political, regulatory, financial and legal risks allocations were found to be inequitable, and PPP participants preferred tight and highly specified contracts.

*To whom all correspondence should be addressed.

\section{Introduction}

The literature suggests that a primary concern in publicprivate partnerships (PPP) in infrastructure provision is that the negotiation of key project risk allocations (RA) among project sponsors, financiers and governments, - key participants in the partnership - is deeply embedded in difficulties arising from unequal power relations, adversarial interests and complexity of the process itself. Invariably, the key factors complicating the process include: differing perceptions about PPP risks with the private sector apprehensive about both market and non-market risks; sensitivity of the project phase to cash flow effects; transparency, fairness, credibility and predictability of the bidding process; and the preference for a project financing approach (Hoffman, 1998; Arndt \& Maguire, 1999a). While this situation has increased frustration and diminished incentives to the private sector, it is exacerbated by perceptions of higher risks in developing countries. Therefore, South Africa being one of such countries, will have to confront the challenge of streamlining its RA processes to mitigate key risks in order to attract private investment in infrastructure.
The purpose of this research was to evaluate public and private sector concerns with RA processes and propose risk allocation refinements that would optimise participants' incentives, ensure quality service and sustain PPP in basic infrastructure provision. The research therefore, explored the processes and outcomes of RA negotiations in PPP projects, developed an RA matrix and tested it against the South African experience with particular focus on: understanding critical factors influencing the RA negotiation process at inception and during implementation; determining the practice of optimal RA and risk sharing in South Africa with reference to theory, principles and practice elsewhere; and assessing the techniques of implementing and regulating the outcome of RA negotiations.

The principle of efficient risk allocation posits that the net economic cost of bearing all allocated risks be minimised. To achieve this, risks should be allocated to persons who not only can bear them but can also do so at the least possible costs. Thus, the greater the ability to influence risks, the lower will be the cost of bearing them. 
The scope of study was limited to risks transferred to private sector participants and those retained by government in a concession-type PPP which is the most common mode.

Section two reviews the literature leading to the generation of testable propositions. The methodology for testing these propositions, analysing and interpreting the results are described in section three. The results are analysed and interpreted in section four and the conclusions of the study presented in section five.

\section{The conceptual fabric}

\section{Key risks in private infrastructure}

Underlying various definitions of risk is the notion of decision-making under uncertainty. The South African Society of Risk Managers (1994:3) define risks as 'the presence of uncertainty ... measured as the variation from the expected outcome of a given situation'. It is the 'exposure to the possibility of economic or financial loss or gain, physical damage or injury, or delay as a consequence of the uncertainty associated with pursuing a particular course of action, (Cooper \& Chapman, 1987:2).

There are two categories of risks - pure and speculative. Pure risks concern the possibility of either a loss or no loss and are insurable. Major types of pure risks are natural risks (floods, drought, famine and earthquakes); internal business operations risks (assets, people, liabilities and internal control); supplier risks (insolvencies, delays or nondelivery); and business delivery risks (public liability, product defects, performance bonds) legislation (professional indemnity, compliance, lawsuits, safety and health).

Speculative risks, also referred to as trading or entrepreneurial risks, are those that could result in either a loss or gain. They are usually not insurable although hedging products have been developed for certain types of speculative risks, particularly financial risks. These risks can be classified as commercial or non-commercial. Commercial risks are risks of doing business and can be influenced by entrepreneurs. They include: economic risks (commodity prices, inflation, currency volatility); market risks (demand patterns, consumer income levels, competition); financial risks (credit risks, interest rates, foreign exchange); technology risks (obsolescence, substitute risks) and resource management and operating risks (factors of production, productivity, environmental risks). Non-commercial risks are usually beyond the influence and control of entrepreneurs and include: sociopolitical and country risks (crime, change of political policy, war and unrest, expropriation, corruption); and legal and regulatory risks (taxation, nationalisation and regulation legal, liability, security of tenure). See Table 1.

Table 1: Key risks in private infrastructure

\begin{tabular}{|c|c|}
\hline RISK TYPE & KEY RISKS RELEVANT TO PRIVATE INFRASTRUCTURE \\
\hline Economic risks & Stability of economic policies, inflation, country credit rating and real exchange \\
\hline Financial risks & $\begin{array}{l}\text { Interest rates, currency risk, project debt and debt maturity, credit risk, cost inflation and cash flow, } \\
\text { creditworthiness of participants / counter parties, syndication / underwriting }\end{array}$ \\
\hline Market risks & Tariffs, off-take, demand and income levels, income inequality and competition \\
\hline Technology risks & Obsolescence of assets and new technology \\
\hline Develop \& construct & Design and planning, construction and completion risks, and handover of project \\
\hline Start-up \& operating & Performance risk and environmental risk, resources utilisation, supplier risks \\
\hline Socio-political risks & $\begin{array}{l}\text { Social and political stability, regional stability, country credit rating, exchange controls, "One-party" state, } \\
\text { income inequalities, corruption, social development and business protectionist pressures, and labour market } \\
\text { stability, social non-acceptance risk }\end{array}$ \\
\hline Regulatory and legal & $\begin{array}{l}\text { Property rights clarity / transparency / predictability of regulatory framework, termination and default risk, } \\
\text { private infrastructure legislation, independence of regulatory regime and judiciary, enforceability of } \\
\text { contracts, access to international arbitration, and track record }\end{array}$ \\
\hline Force majeure & Natural disasters, riot, unrest and acts of war (in SA and SADC region) \\
\hline
\end{tabular}

\section{Risk allocation}

Risk allocation is the process whereby each potential and major risk in a project is identified and allocated to one of the participants in the project (Hoffman, 1998).

There are two core principles involved. First, risks are allocated to the party that is best able to bear and control those risks at their lowest cost. In addition, it is necessary to match returns for each party to the risks they bear, to achieve economic equilibrium. (A' Court \& Laurenson, 1998; Ardnt \& Maguire, 1999a, Carter \& Bond, 1996; Dialami, Lipkovich \& Van Dyck, 1999; Donlon, 1998; Fayard, 1999; Hoffman, 1998; Klein 1998; Shaw, Gwillan \& Thompson 1996; Thobani, 1999; Zakrzewski; 1999). The process is accomplished through the negotiations. 
Application of the two principles in the negotiations does not necessarily reduce risks; it lowers the cost of bearing risk and thus the risk premium on a project.

\section{Public private partnership (PPP)}

PPPs are essentially cooperation and contractual partnerships between public and private sector organisations for the purpose of providing services (not assets) that are normally provided by government (Fayard, 1999; O'Rouke, 1998). A PPP usually spans the entire life cycle of an infrastructure project and includes planning, defining, financing, construction and operation of the project.
The sustainability of PPPs is affected by several macro level factors: legal independence as it guarantees property rights, security of tenure and international arbitration mechanisms to mitigate the risk of participants; political stability and macro-economic indicators of inflation, balance of payment, and country credit rating as they relate to country risk; market structure in regard to the extent of competing infrastructure and pricing of services as they affect market and socio-political risks; local financial market maturity; financial and technical capabilities of government and its agencies; availability and quality of information required for due diligence; tendering practices and processes and the risk profile of the sector and project.

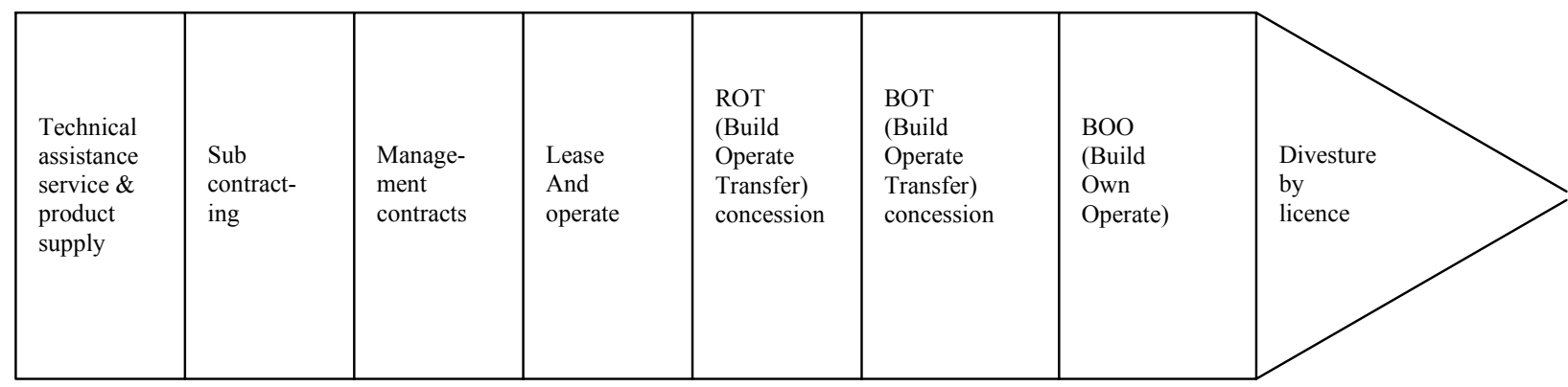

\section{Figure 1: Modes of public-private partnerships}

A PPP comes in different forms - Fig 1. The various modes influence the RA process through the following three parameters - operational efficiency requirements, capital investment and asset ownership - by how these responsibilities are allocated between government and the private sector (Table 2).

The concession-type arrangements - the build-operate-andtransfer (BOT) and rehabilitate-operate-and-transfer (ROT) - are the most advanced forms of PPP and well suited for privatising infrastructure.

A ROT concession gives the private concessionaire responsibility not only for the operation and maintenance of existing infrastructure but also for rehabilitating or upgrading investments. Asset ownership remains with the government and full use rights to all assets, including those created by the private partner revert to the government at the end of the contract - usually after 20 to 30 years. The concession is bid by price and governed by a contract that sets out such conditions as performance targets, performance standards, arrangements for capital investments, mechanisms for adjusting tariffs and arrangements for arbitrating disputes. Socio-political, regulatory and legal risks characterise this mode although market risks are still important to the concessionaire (Shaw et a.l, 1996).

A BOT concession is normally used for new proposals involving large up-front capital investments. The tariff charged is calculated over the life of the contract - also 25 to 30 years - to cover construction and operating cost and provide a reasonable return. In sectors where government or its agency is the purchaser of the infrastructure services, such as water and electricity generation, the BOT contract would normally obligate it to pay for a specified quantity water or electricity, whether or not that quantity is consumed, and thereby placing a demand risk on it. Alternatively, it might pay a capacity charge and a consumption charge - an arrangement that enables it to share the demand risk with the concessionaire.

Thus, in comparison with ROT, BOT bestows on the concessionaire less of market risks and more of sociopolitical, regulatory and legal risks.

\section{Risk allocation in PPP}

The RA process is preceded by request for qualification (RFQ) when bidders are invited to pre-qualify, followed by request for proposals (RFP) when bidders from the RFQ phase are requested to submit their binding bids. During the next phase - the negotiation process - transaction cost could be substantial when no clear regulatory framework has been established. This is followed by the construction phase where the main speculative risks are cost and time overruns and environmental risks. The operation phase, which is the final phase, attracts several commercial and non-commercial risks. The actual RA process, its duration and costs are affected by several micro factors, namely: commercial requirements; bargaining power; financiers requirements; allocation completion risks; nature of the bidding process; the mode of PPP; and participants understanding and perceptions of, as well as apprehensions about PPP risks. 
Table 2: Allocation of key responsibilities under the various modes of PPPS

\begin{tabular}{|c|c|c|c|c|c|}
\hline \multicolumn{6}{|c|}{ KEY CHARACTERISTICS } \\
\hline Modes & Asset ownership & $\begin{array}{c}\text { Operations and } \\
\text { Maintenance }\end{array}$ & Capital investment & $\begin{array}{c}\text { Main risk } \\
\text { bearer }\end{array}$ & Duration \\
\hline Service contract & Public & $\begin{array}{l}\text { Public and } \\
\text { Private }\end{array}$ & Public & Public & $1-2$ years \\
\hline Management contract & Public & Private & Public & Public & $3-5$ years \\
\hline Lease & Public & Private & Public & Shared & $5-15$ years \\
\hline ROT concession & Public & Private & Private & Private & 20-30 years \\
\hline BOT concession & Public and Private & Private & Private & Private & $25-30$ years \\
\hline BOO & Private & Private & Private & Private & $25-30$ years \\
\hline Divesture & $\begin{array}{l}\text { Private or Public and } \\
\text { Private }\end{array}$ & Private & Private & Private & $\begin{array}{l}\text { Indefinite (may be } \\
\text { limited by licence }\end{array}$ \\
\hline
\end{tabular}

Adapted from Brook-Cowen, 1997.

Commercial requirements refer to risk-reward optimisation attributable to various participants aiming to minimise their risks by maximising the risk they transfer to others during the RA negotiation process while also aiming at maximising the expected returns to themselves. This in essence, renders the RA negotiation process as much a returns seek-claimand-match exercise as it is a risk-shed-allocate-and-match exercise. In the absence of a regulation such as price caps or profit control settlement is reached when two opposing forces balance out, at which point the expected returns or risk premium for each party will be commensurate with risks borne by that party.

Lenders provide debt financing to PPP projects with a view to earning an interest return. This exposes them to interest rate risk and are thus often reluctant to finance projects unless borrowers have other sources of debt repayment or the project can be structured on the basis of project finance principles. Lenders will thus demand step-in rights such as the right to replace the project operator in order to minimise the chances of failure. It is for these reasons that lenders would require highly specified risk allocation mechanisms ensuring that no risks remain unallocated and that they are protected against all eventualities.

The allocation of completion risk is important because the construction phase carries the greatest risk, particularly for financiers. Completion of the construction and commissioning of the project is critical for cash flow required to start servicing debt obligations. Sponsors are the primary bearers of this type of risk, but in practice tend to transfer them to contractors, further adding to tensions, particularly if the contractor is not part of the concessionaire.

Perceptual differences about market and non-market risks complicate and retard the RA process. But, negative perceptions and apprehensions about these risks lead to obsessive risk minimisation behaviours among PPP participants.

The challenge of RA negotiations is the temptation of participants to resort to the use of bargaining power. In this regard, government often has the highest bargaining strength leading to uneven bargaining (Arndt \& Maguire, 1999a). On the other hand, the bargaining position of investors is attenuated by the 'obsolescent bargain'effect; that is, once these investors have incurred sunk costs in investing in PPP projects, they are vulnerable to adverse government action or inaction (Arndt, 1998; Dailami \& Klein, 1997).

\section{Roles of PPP participants}

In accordance with the principle of risk allocation the private sector should take commercial risk and government socio-political, regulatory and legal risks. It is however, normal for the private sector to accept some socio-political risk, but there is a danger of reneging on contractual agreements by government should it dare take on commercial risks (Klein, 1997; Shaw et al, 1996). Table 3 suggests a risk allocation framework with the following risk bearer-risk type matching: equity investors - uncontrollable risks; lenders/financiers - interest rate/ foreign exchange risks; operators - start-up and operating risks; contractors development and construction risks; insurers - natural, environmental and limited operating risks; underwriters socio-political credit and currency risk; and government legal, regulatory and socio-political risk.

\section{PPP contracts}

The agreed risk allocation is implemented through contracts which may be tight, flexible or a blend of the two. A tight or rigid contract is usually detailed and specific enough to protect the parties from frequent and politically motivated changes in service requirements. But they also limit easy responses to changing social, economic and technical conditions or the ability to fine-tune original arrangements. Therefore, a delicate balance needs to be struck between highly specified contracts that reduce the role of the regulator to that of monitoring compliance on the one hand, and more flexible arrangements, which allow regulatory discretion on the other hand.

A hybrid of the risk allocation contract and the 'agreement to negotiate' alternative is the Material Adverse Effect (MAE) approach which anticipates certain risks events to be borne by or shared among respective participants. Mechanisms for redress are defined upfront should any such risks occur and cause material adverse effect on the project. These mechanisms include reference to an agreed financial model or to an open book audit of the project. 
Table 3: Risk allocation matrix

\begin{tabular}{l|l}
\hline RISK TYPE & \multicolumn{1}{c}{ IDEAL RISK BEARER (IN SEQUENCE OF PRIMACY OF BEARING } \\
\hline Economic risks & Sponsors / Equity holders, Lenders and Government \\
\hline Financial risks & Lenders, Sponsors / Equity holders, Underwriters an Financial Advisors \\
\hline Market risks & Operator, Sponsors / Equity holders and Regulators \\
\hline Develop and construct & Contractors, Sponsor / Equity holders and Insurers \\
\hline Start-up and operating & Operator, Sponsor / Equity holders and Insurers \\
\hline Environmental risks & Insurers, Contractor / Operator, Sponsors / Equity holders, Regulator \\
\hline Socio-political risks & Government and Underwriters (eg MFI's such as the IFC and MIGA) \\
\hline Regulatory risks & Regulator, Government and Legal advisors \\
\hline Legal risks & Government and Legal Advisors \\
\hline Force Majeure risks & Insurers, Sponsor / Equity holders, Contractors / Operator and Government \\
\hline
\end{tabular}

Adapted from Ardnt, 1998 and Fayard, 1999.

\section{Methodological procedures}

The literature review yielded a number of testable propositions for field study, the methodological procedures involving sampling, questionnaire design and field interview, coding and analysis of data and presentation of results for interpretation.

\section{Research propositions}

- Delayed and costly financial closure as well as the preference for tight contracts are influenced by the following factors:

- Irrational allocation of completion risks;

- Conflicting objectives of PPP participants; and

- Unequal bargaining power wielded at RA negotiations

- $\quad$ Based on the principle of equitable risk allocation, commercial risks are best allocated to the private sector and non-commercial risks to government and its agencies. In practice, however, risk allocation deviates form this principle because of the three factors cited in the above proposition, leading to sub-economic private infrastructure projects.

- $\quad$ Expected returns on private infrastructure projects are commensurate with risks borne, regardless of whether those risks have been allocated equitably or not and regardless of the extent of regulation.

- The material adverse effect (MAE) approach is the preferred means of dealing with risks allocated to parties in PPPs. Financiers, however, prefer tight or highly specified contracts.

\section{Sampling}

The target population for in-depth interview was all executive directors and managers of public and private sector organisations participating in concession-type PPPs in the basic infrastructure sectors in SA. They were targeted for their decision-making positions, expert knowledge of and first-hand experience with complex RA issues.

At the time of this research, there were only a few major concession-type PPPs that had been completed. They were all less than five years old. Therefore, the target population size was limited due to the infancy of the South African PPP industry and the fact that there was a core group of persons who had actually participated in a number of concessiontype PPPs and had interacted extensively with each other.

The sampling frame consisted of all executive directors and managers who had participated in concession-type PPPs up the November 1999 and were based in the Gauteng province of South Africa at the time of the research.

\section{Sampling method and sample}

A combination of judgemental and snowballing sampling methods was used to select the sample. A judgemental sampling method gives the researcher the discretion to select on the basis of a predetermined criterion and in snowball sampling the initially selected respondent is asked to recommend other respondents. Given the limited population and the difficulty in identifying them this was the most appropriate method. Even though probability methods would have been technically superior they were inappropriate in this case.

The final sample consisted of 36 PPP experts of which 30 responded, giving a response rate of 83 percent. Respondents were categorised into four groups of lenders $14 \%$; government officials (regulators, PPP co-ordinators, and government negotiators - 19\%); sponsors (Project sponsors or equity investors, contractors and operators $29 \%$ ) and advisors (financial, legal and technical and insurance advisors $-38 \%$ ). Thus, the sample achieved sufficient cross-representation in terms of expertise. 


\section{Field work}

Exploratory interviews were conducted with five experts, followed by in-depth interviews of the final sample. The interview schedule was based on the research propositions and sought information on the following: background data of the organisation they represented; critical factors influencing the duration and cost of the RA process including recommendations for streamlining the process; South African practice relating to the principle of equitable risk allocation; and the preferred RA contractual arrangements by the various PPP participants.

\section{Methods of analysis}

After editing and coding interview results, frequency ranking correlation as well as chi-square analysis where possible were applied. In cases of no unanimity on ranking order, Spearman rank correlation analysis was applied to ranking order results to test agreement among the various groups. A test of statistical significance was conducted on the Spearman's correlation coefficients using the critical correlation coefficient at a significance level of 0.05 for a one-tailed test.

\section{Results and interpretation}

\section{Critical factors influencing the ra process}

According to the research results the top four critical factors influencing the outcomes of RA negotiation process by frequencies of mention were:

- $\quad$ perceptions and apprehensions about non-commercial risks and market risks, as well as government requirements $(\mathrm{Fa})$

- $\quad$ robustness and adequacy of the regulatory and legal framework $(\mathrm{Fb})$

- $\quad$ lenders requirements $(\mathrm{Fc})$; and

- trade-off between expediency and quality of concession contracts $(\mathrm{Fd})$

- $\quad$ (See Table 4)

Correlation of the frequencies of mention of these factors for all role groups were significant except for lenders and sponsors (Table 5). The poor correlations were evidence of conflicting objectives and dissimilar perceptions. Sponsors were driven by pragmatism and the need for financial closure and thus had the highest frequency of mention of statement $\mathrm{Fd}$ - trade-off between expediency and quality of concession contracts. Particularly weak and insignificant was the correlation between the frequencies of mention of the lenders group and the overall summary. This highlight the higher priority lenders place on lender's requirement as they recorded the highest frequency of mention on statement Fc

Table 4: Comparative ranking of critical factors

\begin{tabular}{|c|c|c|c|c|c|c|}
\hline $\begin{array}{l}\text { Statement } \\
\text { Code }\end{array}$ & $\begin{array}{l}\text { List of factors that influence the duration and costs } \\
\text { of the RA negotiation process }\end{array}$ & $\begin{array}{c}\text { AG } \\
\text { Rank }\end{array}$ & $\begin{array}{c}\text { GG } \\
\text { Rank }\end{array}$ & $\begin{array}{c}\text { LG } \\
\text { Rank }\end{array}$ & $\begin{array}{c}\text { SG } \\
\text { Rank }\end{array}$ & $\begin{array}{c}\text { Sum } \\
\text { Rank }\end{array}$ \\
\hline $\mathbf{F a}$ & $\begin{array}{l}\text { Perceptions / apprehension about non-commercial } \\
\text { risks and/or market risks / Gov. requirements (social, } \\
\text { reg, etc) }\end{array}$ & 1 & 1 & 13 & 5,5 & 1 \\
\hline $\mathbf{F b}$ & $\begin{array}{l}\text { Robustness and adequacy of regulatory \& legal } \\
\text { framework }\end{array}$ & 4 & 13 & 5 & 1 & 1 \\
\hline Fc & Lenders / Financiers requirements & 5 & 13 & 1 & 10 & 3 \\
\hline Ff & $\begin{array}{l}\text { Common understanding among the various PPP } \\
\text { participants of risks }\end{array}$ & 9,5 & 2 & 7 & 4 & 4 \\
\hline Fd & $\begin{array}{l}\text { Trade-off between expediency and quality of } \\
\text { concession contract }\end{array}$ & 3 & 6 & 3 & 10 & 5 \\
\hline $\mathbf{F e}$ & $\begin{array}{l}\text { Commercial requirements (that is risk/return } \\
\text { requirements) }\end{array}$ & 7 & 3 & 8,5 & 7 & 6 \\
\hline Fg & $\begin{array}{l}\text { Bargaining power at play and the relative strengths of } \\
\text { each participant's position }\end{array}$ & 2 & 4,5 & 13 & 14 & 7 \\
\hline $\mathbf{F i}$ & $\begin{array}{l}\text { Allocation of construction risk, or any other early risk } \\
\text { (specify) }\end{array}$ & 6 & 13 & 10 & 2 & 8 \\
\hline Fh & Conflicting objectives of the multiple participants & 12 & 4,5 & 5 & 3 & 9 \\
\hline Fl & Bidders selection \& creditworthiness / risk worthiness & 11 & 7,5 & 5 & 12,5 & 10 \\
\hline $\mathbf{F k}$ & Project financing approach & 9,5 & 6,5 & 13 & 10 & 11 \\
\hline $\mathbf{F j}$ & $\begin{array}{l}\text { Transparency, fairness, credibility and predictability } \\
\text { of bidding process }\end{array}$ & 8 & 10 & 13 & 8 & 12,5 \\
\hline Fm & $\begin{array}{l}\text { Lenders / sponsors / government commitment / } \\
\text { participation and finance certainty }\end{array}$ & 14,4 & 9 & 2 & 5,5 & 12,5 \\
\hline Fn & Macroeconomic and political stability & 13 & 13 & 8,5 & 15 & 14,5 \\
\hline Fo & $\begin{array}{l}\text { Mode of PPP (ie Mgmt Contract or Concession) } \\
\text { adopted }\end{array}$ & 14,5 & 13 & 13 & 12,5 & 14,5 \\
\hline
\end{tabular}


Table 5: Correlation of frequencies of critical factors

\begin{tabular}{|l|c|c|c|c|c|}
\hline & AG & GG & LG & SG & TOT \\
\hline AG & 1,00 & & & & \\
\cline { 1 - 3 } GG & 0,49 & 1,00 & & & \\
\cline { 1 - 3 } LG & $(0,07)$ & $(0,29)$ & 1,00 & & \\
\hline SG & 0,24 & 0,13 & 0,22 & 1,00 & \\
\hline TOT & 0,83 & 0,58 & 0,29 & 0,58 & 1,00 \\
\hline
\end{tabular}

Perceptions and apprehensions about non-commercial risks and market risks, as well as government requirements (Statement $\mathrm{Fa}$ ).

Advisors mentioned this most frequently (10 out of 17) and raised concerns about the low level of socio-political risks government was only willing to bear as well as the lack of political risk cover in South Africa. Predictability of government was therefore essential and clarity on the relative abilities of the three tiers of government to bear and influence risk was necessary. In addition, they were concerned about the culture of non-payment for services, inadequate interpretation of market risks and the likely competition to concessional infrastructure which increased the reluctance to invest.

\section{Robustness and adequacy of the regulatory and legal framework (Statement Fb).}

Advisors raised this issue most predominantly (at a frequency of six out of 14). They were concerned about the fact that PPPs in South Africa were being consummated before the regulatory framework and supporting legislation were in place.

In such circumstances, the RA negotiations became prolonged because of the tendency to expand PPP contracts and include built-in self-regulation the enforcement of which was usually uncertain.

\section{Lenders requirement (Statement Fc)}

This factor related to lenders' requirement for highly specified risk allocation mechanisms that ensured no risks remained unallocated and that as lenders they were adequately protected against all eventualities. All lenders interviewed expressed this concern (six out of 13 times), followed in frequency by advisors (five out of 13 times).

Lenders were adamant that guarantees and assurances from the various PPP participants, termination and compensation provisions, negative covenants, and step-in rights in concession agreements were non negotiable. Essentially they wanted the downside risk identified, quantified, allocated finitely and mitigated because they did not share the upside. Advisors were empathetic with the view, and sponsors were concerned that lenders were unwilling to bear any risk even though the interest rates they charged reflected a risk premium over and above risk-free rates. In sum, lenders wanted certainty while sponsors pursued flexibility.
Trade-off between expediency and quality of concession contracts (Statement Fd)

This factor related to optimising the duration of the RA process by balancing the thoroughness and detail of RA negotiations. The sponsor group mentioned this most frequently (six out of 13 frequencies) as their key concern in RA negotiations. A key issue was the duplication of advisors, which not only led to increased number of negotiators, repetitions and prolonged negotiations but also costly financial closure and a tendency for elaborate contracts.

\section{Other critical factors influencing the RA process}

The next set of factors according to the frequency of mention were:

commercial requirements relating to the risk-return ratio (statement $\mathrm{Fe}$ ); common understanding among the various PPP participants of risk (statement Ff); and bargaining power at play and relative strengths or each participant's position $(\mathrm{Fg})$.

The first factor referred to the goal of: sponsors and contractors to maximise returns at minimum risks; lenders to maximise their return on project debt; and of government to maximise socio and political returns at minimum risks. Government felt that the private sector was obsessive about this goal and could retard optimum risk transfer from government to the private sector and prolong negotiations.

Participants had no common understanding of risks. Indeed, they had differing perspectives on key local specific issues and risks needed to be incorporated in the financial model.

With regard to 'bargaining power' at play and the relative strengths of each participants position, there was absolutely no agreement about the direction of power during the RA process. Each group alleged that bargaining power vested with the other groups with advisors appearing neutral.

These critical factors were in total disagreement with those contained in the research propositions. Furthermore, the factors were all transitional issues relating to South African PPPs being young. As these factors diminish in importance due to learning curve effects those three factors proposed from the literature review will then begin to gain importance. However, if these transitional factors were not addressed satisfactorily, future investment in PPPs would become increasingly unattractive.

\section{Optimal risk allocation}

\section{Key risks}

The key PPP risks considered during RA negotiations in a statistically significant ranking order were: market risks; regulatory risks; legal risks; socio-political risks; financial risks; development and construction risks; start-up and operating risks; force majuere risks; and economic risks (Table 6). 
The top risks were consistent with the top critical factors influencing the RA process, particularly the apprehension about market and non-commercial risks and concern about the robustness and adequacy of the regulatory and legal frameworks.

\section{Table 6: Comparative ranking of risks}

\begin{tabular}{|c|c|c|c|c|c|c|}
\hline $\begin{array}{l}\text { Risk } \\
\text { Code }\end{array}$ & Risk type & $\begin{array}{c}\text { AG } \\
\text { Rank }\end{array}$ & $\begin{array}{c}\text { GG } \\
\text { Rank }\end{array}$ & $\begin{array}{c}\text { LG } \\
\text { Rank }\end{array}$ & $\begin{array}{c}\text { SG } \\
\text { Rank }\end{array}$ & $\begin{array}{l}\text { Sum } \\
\text { Rank }\end{array}$ \\
\hline MR & Market risks & 1 & 4,5 & 1 & 1 & 1 \\
\hline $\mathbf{R R}$ & $\begin{array}{l}\text { Regulatory (incl. Overloading, and termination \& } \\
\text { compensation risks) }\end{array}$ & 2 & 2 & 3 & 4 & 2 \\
\hline SPR & $\begin{array}{l}\text { Socio-political (incl. Gov. credit, and termination \& } \\
\text { compensation }\end{array}$ & 3 & 1 & 6 & 2,5 & 3 \\
\hline $\mathbf{L R}$ & $\begin{array}{l}\text { Legal risks (incl. Overloading, and termination \& } \\
\text { compensation risks }\end{array}$ & 6 & 3 & 2 & 2,5 & 4 \\
\hline FR & Financial risks (incl. Government credit risks) & 7 & 6 & 4 & 5 & 5 \\
\hline DCR & $\begin{array}{l}\text { Develop \& Construct (incl. Environmental \& Performance } \\
\text { risks }\end{array}$ & 4,5 & 4,5 & 5 & 6 & 6 \\
\hline SOR & $\begin{array}{l}\text { Start-up \& Operating } \quad \text { (incl. } \\
\text { Performance risks) }\end{array}$ & 4,5 & 8 & 8,5 & 7 & 7 \\
\hline FMR & Force majeure risks & 8 & 6 & 8,5 & 8,5 & 8 \\
\hline ER & Economic risks & 9 & 9 & 7 & 8,5 & 9 \\
\hline
\end{tabular}

\section{Equitable risk allocation}

In terms of ideal risk allocation, respondents agreed that commercial risks should be borne by the private sector participants and non-commercial risks by government. They felt however, that government should share some of the top commercial risks, notably, market and financial risks because of the ultimate influence government policies and actions have on them. These views are summarised in Table (7). All correlation coefficients were high and significant.

With regard to commercial risks, it was widely held $(70 \%)$ that sponsors should be primary bearers of market risks with government taking a secondary share. Financial risks should similarly be borne by sponsors $(67 \%)$ as part of the risk of entrepreneurship, together with government and lenders as joint secondary bearers $(20 \%)$. Lastly the sponsor group (94\%) including contractors (72\%) should bear development and construction risks (DCR) since they had the best influence and control on DCR.

Regarding socio-political, regulatory and legal risks, virtually all responses ranging from $95 \%$ to $97 \%$ across all role groups indicated that government and its agencies should ideally bear these risks since government had the best influence on them.

Respondents agreed that in practice, the top commercial risks were borne by private sector participants in PPPs and non-commercial risks shared between government as primary bearer and sponsors as secondary bearers. Thus, sponsors were, by default, bearers of residual noncommercial risks that would not be mitigated by government. In the case of socio-political risks sponsors had to share almost equally with government (45\% and $48 \%$ responses respectively) although in regard to regulatory and legal risks government bore proportionately greater risks (Table 7)

These sharing arrangements were necessary due to a number of reasons: the lack of political risk cover in South Africa compounded by the reluctance of government to bear sociopolitical risks; absence of regulatory framework; lack of clarity on the taxation treatment of PPPs; and limited local government influence on the formulation of legislation at national government level.

Comparing the ideal RA and the RA practice in South Africa (Table 7) reveals that the South African RA practices with regard to market development and construction risks are consistent. However, there was a mismatch on sociopolitical, regulatory, financial and legal risks. The advisory group was apportioned no risks in both the ideal and practical allocations; and lenders had only a minimal risk allocated to them. 
Table 7: Summary of ideal RA vs RA practice in South Africa

\begin{tabular}{|c|c|c|c|c|c|}
\hline & Ideal showing & Bearer \% responses & $\begin{array}{c}\text { Bearer in } \\
\text { showing }\end{array}$ & $\begin{array}{c}\text { Practice \% } \\
\text { responses }\end{array}$ & \\
\hline Risk type & Primary & Secondary & Primary & Secondary & $\begin{array}{l}\text { Corr. } \\
\text { Coeff's }\end{array}$ \\
\hline Market risks & Sponsor $(70 \%)$ & Gov $(20 \%)$ & Sponsors $(89 \%)$ & N/A & 0,98 \\
\hline $\begin{array}{l}\text { Socio- } \\
\text { Political }\end{array}$ & $\begin{array}{l}\text { Government } \\
(97 \%)\end{array}$ & $\mathrm{N} / \mathrm{A}$ & $\begin{array}{l}\text { Government } \\
(48 \%)\end{array}$ & Sponsors (45\%) & 0,83 \\
\hline Regulatory & $\begin{array}{l}\text { Government } \\
(95 \%)\end{array}$ & N/A & $\begin{array}{l}\text { Government } \\
(61 \%)\end{array}$ & Sponsors (32\%) & 0,87 \\
\hline Legal risks & $\begin{array}{l}\text { Government } \\
(95 \%)\end{array}$ & N/A & $\begin{array}{l}\text { Government } \\
(69 \%)\end{array}$ & Sponsors (24\%) & 0,94 \\
\hline Financial & Sponsors $(67 \%)$ & $\begin{array}{l}\text { Gov }(20 \%) \\
\text { *Lenders }\end{array}$ & Sponsors $(52 \%)$ & $\begin{array}{l}\text { Lenders } \\
(29 \%)\end{array}$ & 0,86 \\
\hline $\begin{array}{l}\text { Develop \& } \\
\text { Construct }\end{array}$ & $\begin{array}{l}\text { Contractors }(72 \%) \\
\text { or sponsor group } \\
(94 \%)\end{array}$ & N/A & $\begin{array}{l}\text { Contractors }(68 \%) \\
\text { or sponsor group } \\
(93 \%)\end{array}$ & & 0,96 \\
\hline
\end{tabular}

*Qualitatively respondents had overwhelming comments about the ideal need for lenders to share in the financial risk relating to debt financing.

Regarding inequitably allocated risks, socio-political risks was linked to the 'apprehension' factor, regulatory and legal risks to both the apprehension and the 'regulatory and legal framework adequacy' factors, and financial risks to the 'lenders requirements' factor. Furthermore, despite the nonallocation of risks to the advisory group there was an increasing desire to get them bear the professional risk of their advice. It was however, difficult to implement this principle because of their limited risk and credit worthiness and the fact that their potential losses far exceeded their potential upside from a risk-return perspective.

Overall, the research results confirmed the principle of risk spreading as predicted from the research propositions. Participation of multiple groups with differing roles facilitate equitable RA, but the risk premium for those inequitably allocated risks would be higher than if they were allocated equitably representing a higher net economic cost of PPP in SA and thus compromising the efficiency of private infrastructure provision.

\section{PPP contracts}

Respondents preferred tight and highly specified contracts, which specified clear contractual obligations and rights because of their certainty. Tight contracts with built-in flexibility similar to the MAE (the material adverse effect) approach were the second choice. However, statistical conclusions on the significance of the agreement among the various role groups could not be drawn because of the small degree of freedom in the responses.

These results contradict proposition four which anticipated that the MAE would be the preferred form of contracting. They were, however, consistent with the proposition that lenders preferred the certainty of tight PPP contracts.
The preference for tight and highly specified contracts related to the critical factor about unproven regulatory and legal framework. Lenders on their part wanted high certainty and absolute protection, particularly regarding termination and compensation provisions.

\section{Streamlining the RA process}

Respondents made five recommendations for streamlining the RA negotiation process in order to reduce the duration and cost of financial closure:

- Improve transparency and quality of RFPs (request for proposals) and conduct thorough up-front homework before inviting proposals

This recommendation was borne out of the need to verify the project feasibility upfront and prevent the legality of the bid awards being challenged.

- Secure the participation in and commitment to the project by all parties, including political commitment and support

This recommendation reflects what PPPs are all about partnerships between the public and business.

- $\quad$ Promote national standards, guidelines, and regulatory consistency

This recommendation was underlined by the need for national harmonisation and consistency of PPPs and addresses the critical factors affecting the RA process as well as the inequitable allocation of regulatory risks.

- Optimise the utilisation of Advisors 
This recommendation revolved around the concern that advisors got carried away with the RA process if they were not managed properly. This concern applied to legal advisors in particular due to the legislative nature of the RA process. Participants could share advisors to minimise cost, areas of disagreement and the number of negotiating parties. This then would address perceptions and apprehensions on market and non-commercial risks, the critical factor on expediency versus contract quality and the inequitable allocation of socio-political risks.

\section{- $\quad$ Shortening the learning curve}

This is a classical recommendation on transition. Respondents stressed that experience would lessen risk aversion, especially that of lenders leading to faster RA processes. The recommendation would impact on three of the four critical factors influencing the RA processes namely, perceptions and apprehensions on market and noncommercial risks, expediency versus contract quality tradeoff, lenders requirement for high-risk aversion and the track record of legislative support of PPP.

These recommendations fall into two categories administrative issues and transitional issues. The first relate to the procedure of the bidding process, national regulatory frameworks, management of the RA process, commitment and involvement of PPP participants and the motivation for PPPs. The other were issues that would diminish as experience and maturity grew.

\section{Conclusions and implications}

Private sector participation in the provision of basic infrastructure services has brought about improved efficiencies and much-needed private investment. This innovation has helped address the infrastructure backlog in South Africa, the two main mechanisms employed being public-private partnerships and project finance. To facilitate financial closure and sustain these mechanisms a number of challenges had to be overcome, namely: negotiation and equitable sharing of risks; understanding and accommodating often conflicting objectives, requirements and concerns of PPP participants; and implementing clear contractual obligations.

\section{Major findings and their implicaitions}

This study has found that South African PPPs differed from global characteristics in a number of ways, the differences mainly attributable to the wide experience gap - South African PPPs were young, on a steep learning curve, and their participants lowly experienced. As a result, most issues of concern were transitional and were expected to alter with maturity over time. Indeed, the PPP environment was characteristically dynamic, changeable and uncertain, the key factors influencing the RA process being consistent with the critical risks cited.

Market, socio-political, regulatory, legal, financial and development and construction risks were considered key in South Africa, and RA practices regarding the allocation of socio-political, regulatory, financial and legal risks were found inequitable; that is, they detracted form the principle of allocating risks to the party best able to bear and influence them. The inequitable allocation was attributable to the influences of the critical transitional factors.

PPP participants preferred tight and highly specified contracts, motivated by the uncertain outcomes of the impact of transitional factors and discomfort about the lack of proven long-term track record. This implied that PPP contracts would be inflexible to deal with future changes and that this would make PPPs cumbersome to administer and operate. It was, however, inferred from the analysis that there would be a shift towards built-in flexibility and the inclusion of standard provisions in contracts as the South African PPP industry matured. Such a shift would be in line with global practices.

\section{Future research}

Four broad research agendas arise form this study. First, the various RA techniques explored in this research could be applied with necessary modifications to various types of basic infrastructure as well as advanced infrastructure. However, the practical implications of the application are yet unknown. Secondly, on account of our conclusion that new critical factors would gain prominence over transitional critical factors as the industry matured, a study of the actual factors influencing the RA process in a post transition phase would test the validity of our suggestion. Thirdly, it was unclear whether our conclusion that the divergence between the ideal and practical risk allocations was attributable to critical factors influencing the RA process, would remain valid with maturation of PPPs. Testing this assumption will add a great deal to our knowledge base. Finally, further research could involve case studies of specific PPP projects to explore both sector and project specific experiences.

\section{References}

A'Court, A. \& Laurenson, A. 1998: 'Project finance Identifying and allocating risks', n Corporate Finance Law Update Supplement, February. Auckland, New Zealand: Russell, McVeagh, McKenzie, Bartlet \& Co.

Arndt, R. \& Maguire, G. 1999a. 'Private provision of public infrastructure - Risk identification and allocation project'. Unpublished doctoral thesis, Melbourne: University of Melbourne and The Department of Treasury and Finance.

Arndt, R. \& Maguire, G. 1999b. 'The risk identification and allocation project: A new frontier in understanding project risk allocation', Benchmark, June, Issue 21: 5-7.

Arndt, R. 1998. 'Efficient risk allocation in privately funded infrastructure projects'. Presentation at the IEAust MacroInfrastructure Forum, Melbourne, Australia: February 1998.

Brook-Cowen, P.J. 1997. 'The private sector in water and sanitation - How to get started'. In Smith, S (Ed.). The private sector in infrastructure: Strategy, regulations and risk. Washington DC. The International Bank for Reconciliation and Development \& The World Bank, pp 89-92. 
Carter, L.W. \& Bond, G. 1996. Lessons of experience Financing private infrastructure. Washington DC: International Finance Corporation.

Cooper, D.F. \& Chapman, C.B. 1987. Risk analysis for large projects : Models, methods and cases. New York: John Wiley \& Sons Inc.

Dailami, M., Lipkovich, I. \& Van Dyck, J. 1999. INFRISK: A computer simulation approach to risk management in infrastructure project finance transactions. Washington DC: Economic Development Institute of the World Bank, World Bank Group.

Dailami, M. \& Klein, M. 1997. 'Government support to private infrastructure projects in emerging markets.' Paper presented at the Managing Government Exposure to Private Infrastructure Projects: Averting a new-style debt crisis, Cartagena, Colombia, May 1997.

Dailami, M. \& Leipziger, D. 1997. 'Infrastructure project finance and capital flows: A new perspective.' Paper presented at Conference on Financial Flows and World Development, The University of Birmingham, United Kingdom, September 1997.

Donlon, L. 1998. 'The development of project finance techniques', The Treasury Management International Journal, June.

Fayard, A. 1999. 'Overview of the scope and limitations of public-private partnerships'. Presentation by French Ministry of Public Works, Transport and Housing at the European Conference of Ministries of Transport: Seminar of Public-Private Partnerhips (PPPs) in Transport Infrastructure Financing, France.

Hoffman, S.L. 1998. The law and business of international project finance - A resource for governments, sponsors, lenders, lawyers and project participants. The Hague: Kluwer Law International.

Klein, M. 1998. 'Bidding for concessions - The impact of contact design.' In Smith, S. (Ed.). Public policy for the private sector. Washington DC: World Bank.

Klein, M. 1997. Managing guarantee programs in support of infrastructure investment. Washington DC: World Bank Group.

Klein, M. 1996. Risk, taxpayers, and the role of government in project finance. Washington DC: World Bank Group.

Klein, M., So, J. \& Shin, B. 1996. 'Transaction costs in private infrastructure - Are they too high?' In Smith, S. (Ed.). Public policy for the private sector. Washington DC: World Bank.

O'Rouke, C. 1998. 'Public/private partnership finance', International Structured Finance, 4, July.
Serven, L. 19997. Uncertainty, instability, and irreversible investment: Theory, evidence and lessons for Africa. Washington DC: The World Bank.

Shaw, N., Gwilliam, K. \& Thompson, L. 1996. Concessions in transport. Discussions Paper No TWU-27, Department of Transportation, The World Bank.

South African Society of Risk Managers. 1994. Practice statement number 1 on risk management terminology. Sandton: Society of Risk Managers (SA).

Thobani, M. 1999. 'Private infrastructure, public risk', Finance and Development Journal, March: 50-53.

Zakrzewski, R.A. 1999. 'Risk minimisation in project finance'. Technical paper presented at The Law and Business of International Project Finance Seminar, Brisbane, Australia. 